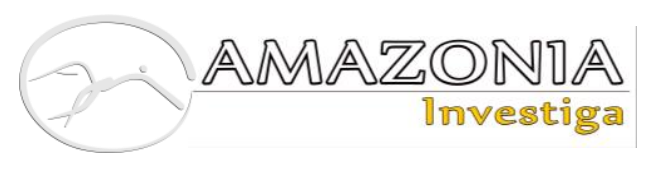

DOI: https://doi.org/10.34069/AI/2021.44.08.10 How to Cite:

Martazanov, A.M., Karabulatova, I.S., Martazanova, K.M., \& Sarbasheva, A.M. (2021). Sacred mythopetronym as a spiritual and moral value of the North Caucasian culture. Amazonia Investiga, 10(44), 103-114. https://doi.org/10.34069/AI/2021.44.08.10

\title{
Sacred mythopetronym as a spiritual and moral value of the North Caucasian culture
}

\section{Сакральный мифопетроним как духовно-нравственная ценность культуры Северного Кавказа}

El mitopetrónimo sagrado como valor espiritual y moral de la cultura del Cáucaso Norte

Received: May 12, 2021

Accepted: July 28, 2021

\begin{abstract}
Mythology is a necessary stage of cultural development in the history of any nation. When a person creates myths, he is in search of the meaning of life and tries to: 1) to fit your life into the framework of a larger whole; 2) to discover a certain structure underlying being; 3) to understand, despite everything, that life has meaning and value. The mythologeme "split stone" in the ethnoculture of the peoples of the North Caucasus, reflected in the novels of the Ingush writer I. Bazorkin, echoes the primitive ideas about the arrangement of the world among different peoples of the world. Since the ethnolinguoculture of the peoples of the Caucasus stands apart among various language classifications, we turn to the analysis of the concept-mythonym "split stone" to identify general and moments of interpretation of the meaning of this concept. Hypothesis: the concept of "split stone" is the basic ethnic idea of the Ingush about the structure of the world order, about the influence of moral qualities of a person on the properties of the surrounding world.
\end{abstract}

\section{Аннотация}

Мифология - необходимый этап культурного развития в истории любого народа. Когда человек создает мифы, он находится в поисках смысла жизни и пытается: 1) вписать свою жизнь в рамки большего целого; 2) обнаружить определенную структуру, лежащую в основе бытия; 3) понять, несмотря ни на что, что жизнь имеет смысл и ценность. Мифологема "расколотый камень" в этнокультуре народов Северного Кавказа, отраженная в романах ингушского писателя И. Базоркин, перекликается с примитивными представлениями об устройстве мира у разных народов мира. Поскольку этнолингвокультура народов Кавказа стоит особняком среди различных языковых классификаций, мы обратимся к анализу концепта-мифонима "расколотый камень", чтобы выявить общее и моменты интерпретации значения этого понятия. Гипотеза: понятие "расколотый камень" является основным этническим представлением ингушей об устройстве

\footnotetext{
${ }^{41}$ Doctor of Philology, Professor of the Department "Russian and Foreign Literature" of the "Ingush state University", (Magas, Russia) ${ }^{42}$ Doctor of Philology, Professor, Department of Foreign Languages, Faculty of Philology, Peoples' Friendship University of Russia (RUDN-university), Moscow, Russian Federation.

${ }^{\mathbf{4 3}}$ Doctor of Philological Sciences, Professor, Head of Department "Ingush Literature and Folklore" of the "Ingush state University", (Magas, Russia)

${ }^{44}$ Doctor of Philology, Head of the Sector of Karachay-Balkar Literature, Institute for Humanitarian Studies-Branch of the Federal State Budgetary Scientific Institution "Federal Scientific Center" Kabarda-Balkarian Scientific Center of the Russian Academy of Sciences", (Nalchik, Russia)
} 
Keywords: mythonym-petronim, North Caucasian fiction, I. Bazorkin, ethnopedagogy, value picture of the world. мироустройства, о влиянии нравственных качеств человека на свойства окружающего мира.

Ключевые слова: мифоним-петроним, северокавказская художественная литература, И. Базоркин, этнопедагогика, ценностная картина мира.

\section{Resumen}

La mitología es una etapa necesaria del desarrollo cultural en la historia de cualquier nación. Cuando una persona crea mitos, busca el sentido de la vida y trata de: 1) encajar su vida en el marco de un todo más amplio; 2) descubrir cierta estructura subyacente al ser; 3 ) comprender, a pesar de todo, que la vida tiene sentido y valor. El mitologema "piedra partida" en la etnocultura de los pueblos del norte del Cáucaso, reflejado en las novelas del escritor ingush I. Bazorkin, se hace eco de las ideas primitivas sobre la disposición del mundo entre los diferentes pueblos del mundo. Dado que la etnolingüocultura de los pueblos del Cáucaso se distingue entre varias clasificaciones lingüísticas, pasamos al análisis del conceptomitónimo "piedra partida" para identificar momentos generales y particulares de interpretación del significado de este concepto. Hipótesis: el concepto de "piedra partida" es la idea étnica básica de los ingush sobre la estructura del orden mundial, sobre la influencia de las cualidades morales de una persona en las propiedades del mundo circundante.

Palabras clave: mitónimo-petronim, ficción del norte del Cáucaso, I. Bazorkin, etnopedagogía, imagen de valor del mundo.

\section{Introduction}

Understanding sacred places in the culture of the peoples of the North Caucasus helps to understand the specifics of ethno-cultural views, helping to build proper intercultural communication. The North Caucasus is located in a mountainous area, so the mountains themselves, as well as their transformations, have a hidden meaning, which is also important for the modern peoples of the North Caucasus. The authors believe that the designation of the mythopetronym "mythologized stone" in the Caucasian ethnoculture has a priority character in the system of ethnic values of the vitality of the ethnos. So, today, the worship of "split stones" is surrounded by myths. It is believed that performing rituals and worshipping a split stone helps infertile women to find the happiness of motherhood, and gives men longevity and health. The article gives an understanding of local holy places in the Caucasian culture, which is an important moment in the formation of successful cross-cultural communication.

The authors consider the evolution of the concept of "Split Stone" in the Caucasian ethnoculture, analyzing both the Caucasian folk epic, legends, and modern works of art in comparison with real historical events that played a role in consolidating folk ideas about the sacred mythopetronym in the culture of the peoples of the Caucasus.
The anthropological paradigm in humanitarianism, which determines the main perspective in the works of recent decades, forces scientists to turn to myths as a cognitive and pragmatic phenomenon of modernity (Barth, 2010; Bespalov, 2010; Rejabek, 2003; Sautieva et al, 2021). Basically, the appeal to mythologems is mainly associated with attempts to describe changes in the structure of the meaning of a myth in comparison with the nomination of a particular phenomenon (Karabulatova, 2013; Savchuk et al., 2019).

In the modern era, there is a revival of mythmaking, which has a significant impact on the entire space of culture, as well as on scientific and philosophical research. The revival of myth at a new turn of history is characterized by a variety and a special specificity of myththinking, which requires its philosophical awareness and comprehension (Aliyeva \& Zayats, 2015). The relevance of the research is determined by the mythologization of the consciousness of modern man and society (Karabulatova, Lagutkina, \& Amiridou, 2021), which determines the sociality of human behavior and worldview orientations. In addition, the emergence of scientific interest in the problem of myth and myth-making is due to the crisis of classical science and classical rationality and contributes to its overcoming. 


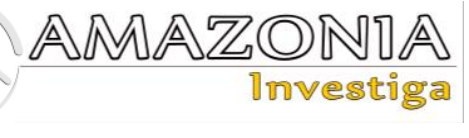

Globalization as a kind of large-scale phenomenon of world development generates profound changes in various spheres of public life. The essence of these changes is difficult to understand, which is the paradox of global changes in society (Galanina, 2013; Karabulatova, Barabash et al., 2019). These difficulties give rise to various apologetic and alarmist myths about the nature of the ongoing globalization processes. One of the alarmist myths that has become popular is the myth of a deadly threat to the cultural diversity of the world because of globalization. There is an opinion that globalization has a creative potential in the form of freedom to choose one's path of development under the influence of global culture and a possible incentive to modernize national culture (Akieva, 2016; Fedotova, 2012).

Myths carry an important irrational component, become part of tradition, play an important role in public life, associatively intertwining with the everyday life of society (Baksheeva et al., 2019). But the myth in modern society has not lost its significance as an important form of public consciousness and representation of reality. Such myths, as a rule, are not part of a long-term tradition that forms the core of culture, but they occupy a considerable place in the fluid mosaic mass culture and solve specific tasks of manipulating consciousness (Barabash et al., 2019).

The question arises about the survivability and effectiveness of myths, despite their ideological and political destructive orientation. Let us consider the reasons for the survivability and effectiveness of myths. The main reason is that myths, like legends, fairy tales, fantasies, are necessary for a person to create inner well-being, spiritual comfort, relieve overstrain, preserve the order of habitual life in an unstable and incomprehensible modern world. In this understanding, the myth becomes a form of selfdeception.

So, the specificity of the myth is that it expresses the needs and interests of a person as a syncretic, pre-reflective, subjective-subjective, irrational, sensual and false form of human consciousness (Belomoeva \& Kondratenko, 2020). Initially, the myth was based on undeveloped (pre-logical), and in terms of psychology-on visual-effective, emotional-practical thinking, sensorimotor intelligence (Zh. Piaget). Thus, the epistemological source of myths was empirical thinking, based in a transformed form on stable undifferentiated sensory-rational constructs of imagination (mythologems), generating an uncritical traditionalist model of cognition of the world.

Folk-Art literature is an aesthetic layer of the national worldview, the worldview in the work of the writer, whose work is permeated with the national mythological worldview. In the works of I. Bazorkin, the myth arises as an attempt to build a holistic picture of the world at the intuitive level of perception, capable of generalizing empirical experience and complementing its limitations.

The need for such research is also dictated by the socio-cultural transmission of the archetypal, with the help of which the ethnos "inherits itself" to its new members, primarily children.

This educational potential of the traditional culture of an ethnic group allows us to perpetuate our identity in future generations, which is important in the context of preserving the cultural diversity of multinational Russia. The second side of the process of translation of cultural universals that dictate certain ideals, norms, value orientations, behavioral models, traditions, and customs, etc.is associated with ethnic socialization.

\section{Materials and methods}

Anthologies and textbook collections of Ingush national folklore, in particular, "Anthology of Ingush folklore", as well as works of art by Ingush writers of the late 20th century were used as a source study base.

The methodological foundations of the study are determined by the specifics of the object and subject of the study, which was carried out considering the fundamental provisions developed by Russian ethnopedagogics on the problems of studying the archetypal in ethnoculture and the material of historians, ethnographers, linguists, and cultural scientists on the problem of the spiritual culture of the Ingush.

The authors also used the following methods:

- the method of comparison, which involves the study of specific facts, their generalization and comparison with other groups of facts;

- the method of philosophical hermeneutics, with the help of which the task of reconstructing the meanings of archaic texts is solved;

- the method of textual analysis, which is an important tool in revealing the content of 
philosophical texts, folklore, and artistic works.

All these methods made it possible to reveal the initial ideas of the Ingush people about man, society, and nature as constituents of the cultural picture of the world. In the analysis of the cultural picture of the world, theoretical constructs were used, developed by well-known Russian philosophers, culturologists and ethnologists: T. M. Alpeyeva (1997), R. Barth (2010), A.Ya. Gurevich (2005), I. S. Karabulatova (2013), and others.

The methodological basis of the research is the principles of cognition of social phenomena: historicism as a component of the modern theory of social cognition, consistency, complexity, the principle of integrity and unity of the historical and logical, etc. Due to the closeness to the method of observing the archetypal under the multilevel layers of the traditional Ingush culture, the methods of interpretation and typing were used in this work. Along with these methods, the specifics of the research problem led to the use of analytical, aggregate methods, as well as the method of field ethnographic research. The socio-philosophical direction of myth research also develops the concept of transformed forms of consciousness (Alpeyeva, 1997; Kopalov, 2012; Mamardashvili, 2019, etc.) So, T. M. Alpeyeva believes that the myth is: "the attribute property of the consciousness, and specific socio-cultural theological education is not reducible to political and ideological concepts and theories, and spontaneous, unconscious sensory-specific views" (Alpeyeva, 1997), a Semiotic approach to the specifics of the myth revealed what it boils down to understanding how language the phenomenon of consciousness. Structuralist R. Barth (2010) puts forward a distinction between" natural language "and "metalanguage" (mythological discourse), which in turn multiplies into different types, considering sociolects. The mythological discourse is formed as a certain inductive system of meanings that are taken not as a subjective system of values, but as an objective system of facts that sensually construct a given and eliminate its historicity. Political science interpretation of myths (V. Pareto, J. Sorel, A. Wiener) believes that myths are an integral part of political ideology the system of society, aimed as a means to manipulate the mass mythological consciousness. So, we can talk about a mass mythologized consciousness, and first this applies to the sphere of politics.
To identify the archetypal in the rituals of the life cycle, the theory of "rites of passage" was methodologically of great importance, in which the emphasis is placed on the mechanisms of overcoming critical boundaries by a person with the help of "correct" forms of ritual communication that have a symbolic character.

\section{Results}

The problem of the formation and development of a person's worldview has been of steady interest to social and humanitarian thought for many years. It is the most important in the educational activities of systems and educational institutions.

In modern conditions, ethnopolitical mythology is becoming an important tool for consolidating society and at the same time is a means of contrasting its members into "friends" and "strangers". It gives a person the strength to overcome everyday difficulties and the hope that all his hardships will pay off with a happy future for all mankind. In this respect, the political myth is deeply dehumanized, since it inspires the idea that his individual life is insignificant in front of social tasks. The concept of "split stone" in the culture of the peoples of the North Caucasus is closely related to the trigger of the tragedy of the Ingush people and ethnorauma (Osipov et al., 2016).

The ethnotrauma associated with the forced deportation of the peoples of the North Caucasus was consolidated thanks to the legends about the sacred petronym "Split Stone". According to the legends of the Ingush and Chechens, the stone splits in days of upheavals and trials for the people or their leaders.

In the attitude of the Vainakhs (Chechens and Ingush) the mountain is the unshakable foundation of life, the basis of the traditional way of life of the mountaineers. The surrounding landscape of the mountains emphasizes this solidity and stability, so the phenomenon of a split stone is a reflection of a certain sociopsychological cataclysm that has been imprinted in nature.

Nowadays, we are dealing mainly with political and ideological myths that have a certain specificity compared to traditional myths. So, if in traditional myths the object of mythologization is gods, cultural heroes, or ancestors, then in political myths these are people and events of the present or recent past. Secondly, political myths are not transmitted by 


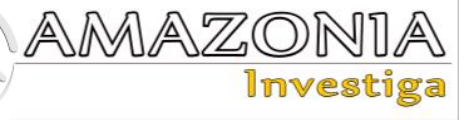

tradition, but are created consciously by certain people or groups of people. They rely on the scientific theories of their time and strive to give political myths have the appearance of verisimilitude and scientific similarity. And finally, the channels of dissemination of modern, especially political myths: unlike archaic ones, occur mainly through the media, and not by oral or handwritten means. For the mythological type of consciousness, it is not the historical event itself that is important, but its interpretation in the existing system of predictions. Therefore, in the myth, the future is strictly determined and can have only one incarnation - the one that has already been predicted. As a result, it is the predictions that have the real reality in the myth, the areal, historical event becomes its echo.

Regarding historical myths, we can talk about the latent and active phase of their functioning. During the active phase, the myth becomes the dominant of public consciousness, covering either the entire society or a large part of it. With the change of public moods, the circle of its adherents narrows, giving way to another ideological model.

Ethnopedagogy explores the totality of human interaction with the ethnic and cultural environment, has various aspects of these interactions in its field of attention, so it can be argued that it originated in the mainstream of philosophy, then pedagogy, gradually acquired the features of an interdisciplinary branch of scientific knowledge.

The study of the sacred sites of the North Caucasus takes place in primary and secondary schools as part of the regional component. Since schoolchildren know about such places thanks to family traditions, teachers pay attention to the relationship of these places with global, European, Islamic, regional and ethnic traditions themselves.

In the traditional pedagogy of the peoples of the North Caucasus, a man is a reflection of the power of the mountain, so he is unshakable like a rock or a mountain, he is powerful as well as a mountain, so a man's word and deed also have irreversible consequences like a rockfall in the mountains. This behavior is gender-specific in the tradition of the peoples of the North Caucasus.

Popular knowledge about education is concentrated in works of oral folk art and in the secondary interpretation of fiction. The theoretical foundations of knowledge and its concepts are applied to the study of folk knowledge on education. In pedagogical and cultural studies, the totality of folk knowledge on the upbringing of the younger generation is considered as wisdom and an integral part of the spiritual culture of each nation. The pedagogical understanding of folk knowledge on education in the history of pedagogy and education is revealed in connection with culture. The principle of the sequence of the development of the knowledge base in folk pedagogy contributes to the formation of a creative approach to its understanding, which is possible based on the integration of knowledge (in the fields of philosophy, pedagogy, cultural studies, psychology, and others). They generally contribute to the further development of ethnopedagogy as a field of scientific and pedagogical knowledge.

The very discovery of the myth and its "decoding" requires close research attention, being directly dependent on the ideological and aesthetic position of the author, his writing skills. This generally ensures the effect of folklore on the recipients. The Ingush novel of the late twentieth century became an original example of the fusion of the canons of realistic narrative and artistic conventions (Eldiev, 2010). The architectonics of such works has a complex structure, since it combines layers of historical facts with the philosophical and ideological reasoning of the author, which is fastened with abstract and folklore-mythological inclusions of background knowledge (Karabulatova, Ebzeeva, \& Pocheshkov, 2017). Similar phenomena are typical for other national literatures of the North Caucasus (Martazanov et al., 2021).

The importance of ethnopedagogy is due, first, to the fact that it integrates humanitarian scientific knowledge, which allows us to form a comprehensive system view of a person as an object of ethnopedagogic influence. Although this study of the genesis of ethnopedagogy is inherently historical and pedagogical, but at the same time, the analysis and coverage of its subject should be given considering the realities of modernity and the prospects for its further development.

The understanding of the world order goes either horizontally (for steppe peoples), or vertically (for mountain peoples). The river becomes the center of the world for the peoples of the plains (Baksheeva et al., 2019), for the peoples of the Caucasus, such a center becomes a mountain, or a sacred mountain. In the Ingush culture, such a center of the universe becomes the stone-rock of 
Hagar-Yerda. The image of a stone, a split stone, becomes the key to understanding the focus of the people's forces in historical moments of trials.

The mystical complex "phenomenon-imageword" is typical for the folklore text, characterizing the incompleteness of the figurative knowledge of the world and its mythoritual interpretation. The archaic consciousness modeled its own image of the universe, its virtual reality, inhabited by a lot of fictional characters who were perceived as really existing next to a person, around him, only invisible.

I. Bazorkin (2001) focuses on myths and folklore motifs to understand the genetic memory - the connection between the past and the present. It is no coincidence that the heroes of his epic works make a spiritual pilgrimage to the national origins, to the past that is the desire for purification, the hope of gaining immunity against the temptations of the world, attempts to awaken the instinct of ancestral connection with the past.

In accordance with the above, the model of linguistic and cultural analysis of the mythologeme can be represented as follows:

1. The semantic structure of the" name " of the mythologeme (according to dictionary definitions);

2. Modern socio-cultural stereotypes representing the mythologeme;

3. Stories-origins (mythological, ritual, folklore, everyday);

4. Elements of the myth formed by this mythologeme (a system of images, end-to-end motives, ritual actions, and attributes);

5. Idiomatics (aphoristics) related to the mythologeme and its interpretation;

6. Transformation of the semantics of the mythologeme: oblivion, reinterpretation, the birth of new meanings, etc.

Here is a variant of the linguistic and cultural commentary of the sacred text on the example of the mythologeme stone, which is characterized by a special symbolic load, including sacred. We will note here only those elements of the semantics of the mythologeme that carry sacred meanings. On the one hand, the stone is a natural symbol of certainty, stability, inviolability, immutability, strength. It is no coincidence that the saimbol of the stone exists in all religions of the world. This is the Kaaba, the worship of which has passed from ancient times into the religion of Muhammad — the "black stone". "Black stones" in most cases are meteorites.
Appearing from the heavenly space, they become symbols of a higher power. In pre-Islamic times, the "black stone" was primarily a symbol of the male creative force of nature, a phallic symbol of the Sun, and under the name "Heliogabal" ("The one whom the Sun sends to the earth") it was revered throughout the ancient world. Steles and obelisks, Hermes, and dolmens were common among the Greeks, Romans, in the Scandinavian countries, among the Egyptians, Druids (menhirs), Celts (Cromlechs), Pelasgians, as well as in all countries of the East. One of the apostles of Christ is named Peter, which also means "stone". A symbol of stability, duration, reliability, immortality, inviolability, eternal, cohesion, indestructibility of the Highest Reality. The stone is the archetype of the sun and creation. On the other hand, it is a deliberate clash with the forces of evil and victory over death. The split stone is a symbol of the struggle between the eternal Light and Darkness. Even such a sketch representation of the symbolic complex, representing the semantics of the stone and the split stone, allows us to conclude that it is necessary to interpret this mythologeme in a broad cultural context, since the marked symbolic meanings are only slightly reflected by dictionary definitions.

In all cultures, the stone, solid and unchangeable, is considered the embodiment of frozen magical powers, so the stone is a tool for divination, making talismans and remedies for healing diseases: from lightning stones, which were considered clouds petrified by fire and thunder, and petrified sea urchins that sweat before rain, to corals, bezoars, and precious stones. It is possible to note the predominance of denotative characteristics of the designated, and even the symbolically labeled block "light, power, magic, struggle, stability" acts here only as a figurative base of the evaluative connotation for the component "spiritual light".

Archetypes are necessary for a person from a psychological point of view, since they create a certain basis for his thinking based on the experience of the past. This experience, concentrated in the tradition, combines elements of both the collective unconscious and consciously developed traditional forms.

The myth, being realized in the author's consciousness of the writer, allows him to create his own universe, going beyond the reality of discourse formation and helping the subject to express himself. All possible forms of consciousness are reflected in the world of culture, but the mythological consciousness 


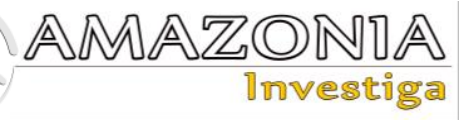

seems to be the most acceptable for use in ethnopedagogy.

The mythopetronym "Split Stone" functions as a mythologism, declared as the main concept of the mythological space of the Nart epic and North Caucasian folklore, lexically embodied in the form of nomina propria and nomina apellativa, therefore this mythologism can grammatically exist in the singular and plural, in masculine, feminine and neuter genders, in one of the forms of the case paradigm. The nominative nature of folklore texts, in which a word is equivalent to an action, sets the focus of consideration primarily of nouns that carry the main semantic load. In relenvant speech, the named power of the name (the name of the entity) becomes the ability of the name to identify a specific denotation in one or many consituations. The naming power of a name is close to conceptual categories.

The entire space of the Caucasus mountains is mythologized.It appears as a carrier of the semantics of the archetype/ mythologeme. This is the so-called memorative level of the token. Thus, just as in the history of religious beliefs, new complexes of ideas did not completely displace the old ones, but layered on them, coexisted with them, each mythologism absorbed and fixed in its semantics changes in the picture of the world of generations.

In the conspiracy, we encounter a special onomastic code that corrects the ethnosociostereotypes of the behavior of an individual, since even the external world of one subject or object is to some extent different from the external world of another subject or object of the same kind. In the sacred discourse of the North Caucasian epic, the mountain space itself acts as a physically existing unity that affects any organism (human, animal, insect) and serves as a source of influence on it. That is why the verbal topography is presented in such detail in Caucasian folklore, marking a sacred place in one way or another. If pain is a misfortune, then it must go beyond the mountains, beyond the limits of "its" space. The semiotic semantic principle of the North Caucasian legend about the split stone is based on the fundamental relationship "microcosm - macrocosm", since the human world and its language have, among other things, their own psychological reality. Every corner of the world surrounding and mastered by man, domestic and natural, is controlled by its own "master" (spirit), to which the storyteller or writer addresses. Here we meet with a kind of "mix" of paganism and religious views of an ordinary native speaker.
In the ancient myth, in pagan beliefs, spiritual properties are expressed through bodily, material manifestations. The demonic world threatens to cause damage to health, well-being, and damage (violation of the norm) is material or physical expression. It was in this socio-cultural situation that the pagan myth, which once performed a sacred task in close connection with rituals, gradually transformed into a folklore text. The text of the myth in pagan culture was esoteric, that is, it was a carrier of secret knowledge for initiates.

In addition, a significant place in the sacred discourse of the North Caucasian epic is occupied by certain behavioral signs - ritual sacred events, which are understood as actions of a ceremonial nature. For example: rolling an egg on the patient's body when removing the evil eye or damage, jumping on the tops of the mountains of the heroes of the epic to harmonize the space, worshipping lonely standing stones for the treatment of infertility, wrapping the patient's body with copper wire in a rite to remove damage, passing through a scabbard (scissors) or a saber to enhance sexual charisma, etc. In this case, ritualism is realized as predictability, programming, traditionality, the predominance of fatica over information in the sacred rite, which is aimed at actualizing the feeling of satisfaction and joy from achieving the goal.

According to K. K. Kolin, " ... In the process of globalization of society, several destructive factors can already be observed today, which deform and even destroy individual structural components of society and, therefore, will have to lead it to partial degradation. In recent years, these factors have become more and more noticeable in the field of culture. Therefore, their analysis, as well as the prediction of possible consequences, seem very relevant both for science and for practical activity ... From a cultural point of view, the globalization of society means a new humanitarian a revolution, because of which many traditional national and ethnic cultures are undergoing significant changes, and some of them may be not only deformed, but also destroyed" (Kolin, 2008: 2-10). The result of such game strategies with an ethno-socio-cultural identity (Karabulatova, Barabash et al., 2019; Nijiati, et al, 2020) is the transformation of the socio-cultural matrices of human society (Karabulatova et al., 2017).

The story of the tragic fates of young people has a tangible emotional impact on the consciousness of the young hero of the novel, forms his thinking. K. Sultanov's statement regarding the 
image-symbol of the "wounded stone" by Kaisyn Kuliyev is quite applicable to this context: "The memory of a native stone is not only a symbolization of unbrokenness and steadfastness, not only a reminiscence of sensory and tactile sensations left in the past, but also an endless spiritual pilgrimage to the roots and source, equivalent to finding the meaning of life. The stone, without losing its clarity and material objectivity, acquires a metaphysical dimension" (Sultanov, 2017, pp. 233-234). The appeal to the folklore and historical past ensures the use of new technologies in the formation of ethnic and socio-cultural identity among a new generation of young people focused on the use of electronic and mobile gadgets (Entina et al., 2021).

To understand the genetic memory - the connection between the past and the present, I. Bazorkin focuses his attention on ancient myths and folklore motifs. It is no coincidence that the heroes of his epic works make a spiritual pilgrimage to their national origins, to the past, which, according to the definition given by the writer himself in an interview, is a desire for purification, a hope to gain immunity against the temptations of the world, attempts to awaken the instinct of ancestral connection with the past.

\section{Discussion}

The unquenchable attention to this problem is determined primarily by the fact that the fundamental categories of the worldview that make up its system-structural matrix are the categories "world" and "human" (Karabulatova et al., 2017), the real essence of which to a large extent has not yet had an adequate scientific explanation and remains largely mysterious and unsolved. The significance of this problem is also explained by the fact that the worldview is the highest form of human self-consciousness, which allows him not only to orient himself in the surrounding reality, but also, based on a certain understanding of reality, to consciously regulate his life activity. This allowed Kazan Scientists to assert that the regional ethno-linguistic culture has a huge linguistic and pedagogical potential in teaching minority languages and cultures, which is a key factor in preserving identity (Zamaletdinov et al., 2014). However, R. R. Zamaletdinov does not consider in detail the role of background knowledge of traditional folk pedagogy as an ethno-saving factor in the era of mobility of ethnosociocultural borders. However, in his works he emphasizes the role of the so-called amulet spirits who live in the sacred places of a particular ethnic group. At the same time, we see a difference in the perception of space among the ethnic groups of the "mountains" (the peoples of the North Caucasus) and the ethnic groups of the "fields" (Tatars, Bashkirs).

Today, when the changes in society are so great that they cause fear of a possible violation of their own identity, it is especially important to preserve the role of traditional forms of life, in particular rituals of the life cycle, where the sacred knowledge of the ethnos occupies a significant place, which is preserved thanks to ethnopedagogy and folklore. The sacred mythopetronym "The Broken Stone" enhances the emotional perception of the fate of the native people, encouraging empathy and the formation of life values that activate the affectiveemotional sphere of the personality of the recipient of folklore discourse.

The famous researcher-philosopher G. Gachev argued that ethnic groups are aware of themselves in the world vertically and horizontally. A "vertical" attitude is characteristic of mountain peoples, therefore the symbolic figure, emblem, model of the world for the North Caucasus is a "bowl up and down" (Gachev, 2008: 28), in other words, infinity of movement, if we complete the image of bowls up to eights ... This is the desire of the spirit to cognize the infinity of the world of the real and the surreal. Stones, mountains, rocks, towers - all this has an aspiration upward, into space, bringing one closer to God. At the same time, the very symbol of the "shattered stone" denotes the futility of the aspirations of the chulovsky spirit, deprived of the support of ancestors, trampled by circumstances, surrounded by enemies. In this sense, the "Broken Stone" acts as a symbol of patience, that it is necessary to gather strength in order to become whole again.

Some researchers of the North Caucasian novel believe that the split stone carries the semantic load of a harbinger of the misfortunes of the Ingush people and subsequent deportation (Gileva, 2017; Tumgoeva, 2013). In turn, this requires a careful selection of language tools (Galanina, 2013; Malevinsky et al, 2019; Vorozhbitova et al., 2019).

In other words, in the people of the middle of the twentieth century, changes took place, which acted as subjective grounds for objectively manifesting themselves tendencies of social development. During this period, the processes of transforming the people themselves, the processes of their personal structure, became active. The transformation of the value-semantic 


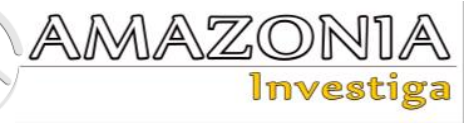

foundations of being, the mechanisms of life selfdetermination, the change in determining tendencies. However, scientific analysis did not keep up with the speed of these processes, and they found themselves on the sidelines of scientific existence (Klochko, 2013: 107). During this period, poets and people of other creative professions are on the "forefront of comprehension", therefore, turning to this paradigm shift is natural in the work of North Caucasian writers (I. Bazorkin and others).

Thus, the legend about the Big Stone of the Nart Debit, a symbol of immortality, interpreted in the North Caucasian novel, presented as a bright touch to the picture of the world in artistic perception, draws the reader's attention to ethnic roots. This is considered an important moment for preserving one's own identity in the conditions of aggressive environmental pressure (Sautieva et al., 2020; Savchuk et al., 2019).

The thousand - year-old stone of the Nart blacksmith Debit, split into two parts (as well as the broken stick of old Zharnes) in the context of the narrative is endowed with the function of a symbol as a tragic prophecy: it is represented as a sign of an impending big trouble in the life of the people-deportation. Harmoniously fitting into the artistic structure of the novel, the designated folklore component actualizes the problem of spiritual continuity, enriching the content of the work with a deep philosophical meaning (Gileva, 2017; Karabulatova, Ebzeeva, \& Pocheshkhov, 2017; Tumgoeva, 2013). As the aesthetic experience shows, the natural object stone, which has been genetically "established" in the Ingush oral literature, finds creative meaning in the North Caucasian art novels of the Vainakh culture in the process of the evolution of artistic thinking (Dolgieva, 2019; Yandieva, 2008).

Today, when the changes in society are so great that they cause fear of a possible violation of their own identity, it is especially important to preserve the role of traditional forms of life, in particular rituals of the life cycle, where the sacred knowledge of the ethnos occupies a significant place, which is preserved thanks to ethnopedagogy and folklore.

Poetizing a natural object, Caucasian writers raise the problems of the spiritual evolution of man. Thus, the motive of the continuity of moral and spiritual values that have been formed for centuries is actualized. For the artistic solution of this problem, folklore elements are used to delve into the precepts of the ancestors, to comprehend the original moral essence of the relations of the living with the living. (Yandieva, 2008).

North Caucasian writers creatively interpret legends and folk songs, consciously focus on the natural component-the stone, which "is the oldest archetypal core of the Karachay-Balkar ethnoculture, generating a whole range of conceptual readings due to mythological, heavenly "roots" and earthly, modern "branches" of the image" [Kuchukova, 2015, p. 147], since topoobjects have always been and remain the center of mythologized associative thinking of a person (Baksheeva et al., 2019; Islamova et al., 2020).

The image of the stone in the North Caucasian novel is multifunctional: it is a silent witness to the tragic circumstances in the fates of the characters of the folk song-crying and a symbol of the sad fate of its heroine. The narrative shows the idea of stones, which is characteristic of mythopoetic consciousness, as witnesses and judges (Dolgieva, 2017; Kuchukova, 2015), therefore, a split stone is perceived as a "storyteller stone", talking about the tragic fate of a person and a people.

\section{Conclusion}

Thus, the appeal of the Vainakh writers to the spiritual and moral experience of the peoples of the North Caucasus contributed to the achievement of versatility in depicting the personal destinies of the heroes in their close intertwining, in revealing the complex interdependence of the psychological and social in the characters, in depicting the national picture of the world. The rich oral and poetic heritage helps to understand the personality in the concept of history and man, thereby determining the ethnic essence of the North Caucasian peoples.

The specificity of the relationship of national literature with oral and poetic creativity is determined in the artistic assessment of ethnopsychology, the actions of the actors from the positions of traditional folk ideas about dignity, honor, wisdom, courage, nobility, and heroism, embedded in the ethnic consciousness. Folklore motifs in the fiction of the North Caucasus mark the conditions for recreating the national picture of the world, acting as the most important feature of strengthening the ideological and philosophical principle in the work of Vainakh writers. The synthesis of folklore and artistic traditions in epic works contributes to the expansion of the poetic possibilities of verbal art, the range of creative thinking of the authors, determining in the future 
the innovative nature of solving complex ideological and aesthetic problems of forming and preserving ethnic identity. At the present stage, folklore remains an inexhaustible source of wisdom, subtlety of world perception, humanism in a high ethical and aesthetic sense for national literatures.

\section{Bibliographic references}

Akieva, P. H. (2016). The history of the ancient beliefs of the Ingush (based on the material of mythology and the Nart epic). Magas: Ingush Research Institute of Humanities named after Ch. E. Akhriev; KEP, 374 p. ISBN 978-54482-0016-8

Aliyeva, N. Z., \& Zayats, Z. V. (2015). Paradigm Foundations of Modern Science: SelfOrganization, Evolution. Integrity Mediterranean Journal of Social Sciences, 6(3) (S4), pp 79-102. DOI: $10.5901 / \mathrm{mjss} .2015 . v 6 n 3 \mathrm{~s} 4 \mathrm{p} 97$

Alpeyeva, T. M. (1997). Introduction to cultural studies. Minsk, 53 p. ISBN 985-6390-06-0

Baksheeva, V. G., Islamova, Yu.V., \& Karabulatova, I.S (2019). Verbal toponymic associations (features of perception of the hydronym Manja by Russian and indigenous population of Yugra). Bulletin of Ugric Studies, 9(4), C. 607-613. DOI: 10.30624/2220-4156-2019-9-4-607-613

Baltabayeva, Z., Sautieva, F., Skorobogatova, A., \& Mamatelashvili, O. (2020). The impact of success factors on the strategic management in an educational complex. Amazonia Investiga, 9(29), 336-346. https://doi.org/10.34069/AI/2020.29.05.38

Barth, R. (2010). Mythology. Translated from the French, introductory article, and commentary by S. Zenkin. Moscow: Akad. Project. Fr. project, 351 p.; ISBN 978-58291-1239-4.

Bazorkin, I. M. (2001). From the darkness of centuries. Collected works: In 6 volumes: Novellas, short stories, Vol. 1. Magas: Serdalo Publishing House, 384 p. https://www.libfox.ru/216991-151-idrisbazorkin-iz-tmy-vekov.html

Belomoeva, O. G., \& Kondratenko, Yu. A. (2020). Ethnocultural tradition I the modern world: functional aspect. Finno-Ugric world, No. $4 . \quad$ URL: https://cyberleninka.ru/article/n/etnokulturna ya-traditsiya-v-sovremennom-mirefunktsionalnyy-aspekt

(accessed: 19.07.2021).

Bespalov, Yu. V. (2010). Myth in the mass consciousness of modern society. Bulletin of VSTU, No. $7 . \quad$ URL: https://cyberleninka.ru/article/n/mif-vmassovom-soznanii-sovremennogoobschestva (accessed: 17.07.2021).

Dolgieva, M. B. (2019). 75th anniversary of the deportation of the Ingush people 1944-1957. Magas: Ingush State University, 312 p. ISBN 978-5-98864-085-1.

Eldiev, A. (2010). The specifics of the ethnoreligious mentality of the Ingush. Personality development. \#1. URL: https://cyberleninka.ru/article/n/spetsifikaetno-religioznoy-mentalnosti-ingushey (accessed: 15.07.2021).

Entina, T., Karabulatova, I., Kormishova, A., Ekaterinovskaya, M. \& Troyanskaya, M. (2021). Tourism Industry Management in the Global Transformation: Meeting the Needs of Generation Z. Polish Journal of Management Studies, 23(2), 130-148. DOI: 10.17512/pjms.2021.23.2.08.

Fedotova, V. G. (2012). Modernization and culture. Knowledge. Understanding. Skill, \#4. URL: https://cyberleninka.ru/article/n/modernizatsi ya-i-kultura (accessed: 17.07.2021).

Gachev, G. (2008). Mentality of the peoples of the world. Translate. M.: Algorithm, EKSMO, 544 p. [in Russian] https://platona.net/load/knigi_po_filosofii/ps ikhologija/gachev_g_mentalnosti_narodov_ mira_2008/22-1-0-1644

Galanina, E. V. (2013). Myth as reality and reality as myth: mythological foundations of modern culture. Moscow: Academy of Natural Sciences, 130 p.; ISBN 978-5-91327218-8.

Gileva, E. F. (2017). On the issue of documentality of Russian-language prose by I. A. Kodzoev. Bulletin of BSU, No. 6. URL: https://cyberleninka.ru/article/n/k-voprosuo-dokumentalnosti-russkoyazychnoy-prozyi-a-kodzoeva (accessed: 18.07.2021).

Gurevich, A. Ya. (2005). History - an endless dispute: Medieval studies and Scandinavistics: articles from different years. Moscow: Russian State Humanit. un-t, 891 p.; ISBN 5-7281-0657-9.

Islamova, Yu. V., Baksheeva, M. G., Vykhrystyuk, M. S., \& Karabulatova, I. S. (2020). Semantics and etymology of substrate hydronyms of the Lower Konda. Questions of Finno-Ugric studies, 10(4), pp. 662-671. DOI: 10.30624/2220-4156-202010-4-662-671.

Karabulatova, I. S., Ebzeeva, J. N., \& Pocheshkhov N. A. (2017). Tolerance problems in the context of the repressed Caucasians' ethno-trauma transformation as "LIGHT" and "DARKNESS". Terra Sebus, 


\section{AMA AZONOA}

447-459.

9,

https://www.cclbsebes.ro/docs/Sebus_9_201

Karabulatova, I., Barabash, O., Barabash, V., Vinogradova, N., Kulikov, S., \& Izbassarova, F. (2019). Homo Ludens in modern postmodern discourse: new possibilities of manipulation of public consciousness. Advances in Social Science, Education and Humanities Research, vol 374. International Conference on Man-Power-Law-Governance: Interdisciplinary Approaches (MPLG-IA 2019), Atlantic Press, pp.48-50. https://www.atlantispress.com/proceedings/mplg-ia$19 / 125925278$

Karabulatova, I., Vildanov, Kh., Zinchenko, A., Vasilishina, E., \& Vassilenko, A. (2017). Problems of transformation matrices modern multicultural identity of the person in the variability of the discourse of identity Electronic Information Society. Pertanika Journal of Social Science \& Humanities, No. 25(S), p. 1-16. http://www.pertanika.upm.edu.my/resources /files/Pertanika\%20PAPERS/JSSH\%20Vol. \%2025\%20(S)\%20Jul.\%202017/JSSH(S)0376-2017.pdf

Karabulatova, I.S. (2013). The problems of linguistic modeling of new Eurasian linguistic personality in multilinguistic and mental environment (by example of onomasphere). Middle-East Journal of Scientific Research, 17 (6), 791-795, 2013. ISSN 1990-9233. (C) IDOSI Publications, 2013. DOI: 10.5829/idosi.mejsr.2013.17.06.12262.

Klochko, V.E. (2013). Ontology of meaning and meaning formation (reflections in connection with the anniversary of OK Tikhomirov). Bulletin of Moscow University. Series 14. Psychology, No. 2, p. 106 - 120. URL: https://cyberleninka.ru/article/n/ontologiyasmysla-i-smysloobrazovanie-razmyshleniyav-svyazi-s-yubileem-ok-tihomirova (date of access: 08/18/2021).

Kolin, K. K. (2008). Man in the knowledge society: new tasks for education, science and culture. Bulletin of the Association of Universities of Tourism and Service, No. 1. URL:

https://cyberleninka.ru/article/n/chelovek-vobschestve-znaniy-novye-zadachi-dlyaobrazovaniya-nauki-i-kultury (accessed: 18.07.2021).

Kopalov, V. I. (2012). The original character of the Russian people: a monograph. Yekaterinburg: Publishing house of the Ural University, 273 p. ISBN 978-5-7996-0703-6
Kuchukova, Z.A. (2015). Karachay-Balkarian vertical. Nalchik: Elbrus, 304. ISBN: 978-57680-2683-7

Malevinsky, S. O., Sultan Aziz, A., Karabulatova, I. S., Luchinskiy, Y. V., Fanyan, N. Y., Grushevskaya, E. S., \& Zelenskay, V. V. (2019). Main types of values of full-numerication words. Religación. Revista De Ciencias Sociales Y Humanidades, 4(16), 156$163 . \quad$ URL: http://revista.religacion.com/index.php/relig acion/article/view/326

Mamardashvili, M. K. (2019). The Arrow of Knowledge. Editor Elena Mamardashvili. Moscow: Merab Mamardashvili Foundation, 270, p. ISBN 978-5-6043463-0-3.

Martazanov A.M., Martazanova Kh. M., \& Sarbasheva, A. M. (2021) Folklore and literary continuum in the North Caucasian novel of the late XX-th century in the aspect of ethnopedagogy. Eduweb, Revista de Tecnología de Información y Comunicación en Educación, 15 (2), 275-291, doi: https://doi.org/10.46502/issn.1856$7576 / 2021.15 .02 .21$

Nijiati, A., Karabulatova, I., Yuan, L. and Sautieva, F. (2020). Problems of cognitive distortions in cross-cultural communication when using automatic translation in the Russian Chinese dialogue. International Scientific Forum "Issues of Modern Linguistics and the Study of Foreign Languages in the Era of Artificial Intelligence (dedicated to World Science Day for Peace and Development)" (LLT Forum 2020) Volume 88,

DOI https://doi.org/10.1051/shsconf/2020880300 4

Osipov, G., Karabulatova, I., Shafranov-Kutsev, G., Kononova, L., Akhmetova, B., Loskutova, E., \& Niyazova, G. (2016). Ethnic trauma and its Echo in today's mental picture of the world among the peoples of the post-soviet states: an interethnic conflicting discourse unfolding in Russian's ethnolinguistic information space. Central Asia and the Caucasus. Journal of Social and Political Studies, 17(2), pp. 8794. URL: http://www.cac.org/journal/2016/journal_eng/cac02/10.shtml

Sautieva, F. B., Radzhabov, I.M., Karabulatova, I.S., \& Pakhomenkova, O.M. (2021). Mythologization of inner space of the North Caucasus and folklore. EduWEB. Revista de Tecnología de Información y Comunicación en Educación, 15(2), p. 292-305. DOI: 
https://doi.org/10.46502/issn.18567576/2021.15.02.22

Savchuk, I.P., Karabulatova, I.S., Golubtsov, S.A., Zelenskaya, V.V., \& Akhmetova, B.Z. (2019). Language features of the legend's genre as the basis of storytelling technology in advertising discourse. Amazonia investiga, 8(21), pp. $\quad 522 \quad 530$. https://amazoniainvestiga.info/index.php/am azonia/article/view/132

Sultanov, K. K. (2017). Nostalgia for stone, or the will to identity / K. K. Sultanov. Artistic experience of Kaisyn Kuliev in preserving Russian cultural identity. Materials of the AllRussian scientific conference dedicated to the 100th anniversary of the birth of the people's poet of Kabardino-Balkaria, laureate of the State Prizes of the RSFSR and the USSR, laureate of the Lenin Prize Kaisyn Shuvaevich Kuliev (1917-1985. Nalchik: Print Center, 230 -239. ISBN 978-5-90677163-6

Tumgoeva, T. A. (2013). The deportation of the Ingush people: a psychological aspect.
Bulletin of GUU, No. 9. URL: https://cyberleninka.ru/article/n/deportatsiya -ingushskogo-naroda-psihologicheskiyaspekt (accessed: 18.07.2021).

Vorozhbitova, A., Karabulatova, I., Bzegezheva, Z., Druzhinina, V., \& Pyankova, T. (2019). A glossy magazine discourse of the early twenty-first century as a tool of globalization: Sochi school of linguistics and rhetoric. Amazonia Investiga, 8(24), 170-180. Retrieved from https://amazoniainvestiga.info/index.php/am azonia/article/view/969

Yandieva, M. D. (2008). The deportation of the Ingush. Falsifications and the real reasons. Nazran: Memorial; Moscow: Elbrusoid, 53 p. ISBN 5-910-75-002-X

Zamaletdinov, R.R., Karabulatova, I.S., Yarmakeev, I.E., \& Ermakova, E.N. (2014). Linguo-Propaedeutics of ethnic conflicts as a basis for stability in complex polyethnic regions. Asian Social Science, 10(20), 164173. doi:10.5539/ass.v10n20p164 